\title{
Utilization of Modern Technologies for Service Delivery in Special Libraries in South-East Nigeria
}

\author{
Justina Ngozi Ekere ${ }^{1}$ \\ Ozioma Ebele Ewulum² \\ Monica Eberechukwu Eze E $^{3}$ \\ Helen Nneka Okpala ${ }^{4}$ \\ Maxwell Ebobo5
}

Nnamdi Azikiwe Library, University of Nigeria Nsukka ${ }^{\mathbf{1 , 2 , 4} \& 5}$

Library and Information Science Department,

Enugu State University of Science and Technology ${ }^{3}$

Corresponding author: justina.ekere@unn.edu.ng

\begin{abstract}
Modern technologies are part of the tools that can help to provide efficient and effective service delivery in libraries. For librarians to perform their jobs effectively, they have to fully utilize modern technologies. The aim of the study therefore, is to examine the utilization of modern technologies for effective service delivery in selected special libraries in South-East, Nigeria. Specifically, two objectives and two research questions guided the study. The study adopted descriptive survey design. Responses to a structured questionnaire developed by the researchers were received from 30 librarians. The questionnaire was entitled,' Utilization of Modern Technology for Effective Service Delivery Questionnaire(UMTSLCQ). It was validated by experts and its reliability index was calculated as 2.50 using frequency table. The data collected were presented in a tabular form for clarity, analyzed using frequency count and tables. The findings of the study showed that modern technologies are not being utilized adequately in service delivery in most special libraries in the south east, although they complement many of the services provided by the special libraries. Recommendations were made based on the findings which includes proper sensitization of librarians on appropriate use of modern technologies, adequate funding, consistent and constant training of staff to upgrade their skill on the use of modern technologies. The study concluded by making recommendation based on the findings.
\end{abstract}

Keywords: Modern technology, Utilization, Service delivery, Special Libraries, South-East Nigeria

\section{Introduction}

The growth and success of any organizations is largely dependent on the amount of current information at their disposal. To meet up with the unsatisfied need for information, modern technology becomes an essential tool needed to do the job of information acquisition, storing and dissemination. Modern technology and Information Technology can be used interchangeably and it refers to all technologies that is used for dissemination of information. The concept of modern technology as a universal information technology is the new science of information collection, storage, processing and transmission. However, Modern technologies connotes an ensemble of technologies which covers computer and storage technologies, to store and processing 
information known as information processing, connected together with telecommunication technologies, which are capable of transmitting information to distances. Information technology covers all aspects of arts, or science of processing data to produce information(Udin and Hasan, 2012). The emergence of computers and telecommunication technology has popularized electronic access to information. Modern technologies comprises of both Information Technology (IT) and Information Communication Technology (ICT). Information Technology covers the application of computers to store, retrieve, transmit and manipulate data. Information Technology (IT) is the use of any computer storage networking and other physical devices, infrastructure and process to create, process, store, secure and exchange all forms of electronic data (Rouse 2015). It is also the coming together of computing and telecommunications for the purpose of handling information; including generation, storing, processing, storage and dissemination of information -textual, numerical, pictorial, and vocal. In other words, technology involves the development, maintenance and use of computer systems, software and networks for the processing and distribution of data.
The use of Modern Technologies in special libraries to enhance effective service delivery is extremely overwhelming. The incorporation of technology into the library has affected its functioning at multiple levels: new configurations of searching space, autonomous and active learning processes using the technology has been adopted also; librarians traditional roles have been expanded, which include teaching users how to use the new technologies.

Modern technologies are resources, products or process with an underlying technology base composed of computers (both hardware and software) workstations or computerized, communication networks of all types including local area network (LANs) wide Area network (WANs) intranets, internet, robotics and smart chips (Shayo 2003). Technologies are fast becoming an essential tool in library and information service delivery, it has had many positive effects on almost all facets of human activities. Issa (2010) submitted to the fact that the advent of Technology in libraries has seen the introduction of electronic services like computerized subscription, library software's, Bibliographical utilities, Resource sharing 
and the internet, thus culminating into a face lifting modern librarianship. Issa (2010) discovered that attempts have been made during the last two decades to incorporate the use of technology into library and information dissemination through the rigorous efforts of library professionals, libraries saw their advent in their present shape towards the 20th century, the application of these information technologies -computer, telecommunications and documents reproduction gave birth to information revolution. This made libraries to embrace and adopt the great touch of these technologies. Initially, library staff functions were limited to manual practices such as cataloguing, acquisition, shelving and shelf reading, user education, accessioning, charging and discharging , serials management which was very tedious and slow and users experience few benefits from these services. UNESCO(2001) defined special library as libraries that are attached to various bodies such as parliament or government departments, a scientific or other research institution .Cloonan (2003) defined special libraries as a collection of information covering a specific field which may be administered by a special staff and for service of a limited clientele.
Technology has changed the expectations of library patrons; people today expect to be able to find and access information from wherever they are (Karl Kalseth 2010). In 2010, nearly 300 million Americans used library services including onsite computers and onsite Wi-Fi to check out books, to attend workshops, and to consult with reference librarians. (Rendon, 2014). In this changing landscape, libraries are trying to adjust their services to these new realities while still serving the needs of patrons who rely more traditional resources. The main purpose for utilizing technology in the library is to extend human capability through the enhancement of the services mentioned earlier which have been provided manually but can now be done faster and more accurately through modern technologies.

Service delivery framework is a set of principles, standards, policies and constraints used to guide the design, development, deployments, operation and retirements of services delivered by a service provider with a view to offering a consistent service experience to a user community in a specific business context. Service delivery is a component of business that defines the interaction between service 
providers and clients where the provider offers a service whether that be information or a task and the client either finds value or loses value, therefore a good service delivery should provide the recipients with an increased value .Service delivery is also the act of providing a service to a customer.

From the above discussions and definitions of service delivery it becomes quite glaring that Speedy access to and use of accurate information strictly depends on the methods of efficient service delivery employed in the library. Information service delivery comes in various forms, channels or strategies such as indexes, card catalogue; online catalogue etc .Service delivery is a service a supplier gives to his or her customers. Service delivery therefore as used in the context of this study refers to usage of modern technologies in special library to provide adequate timely information for use by library patrons.

\section{Modern Technologies in the Special Library Environment}

Information centre or library is the heart and soul of an organization. There is no doubt that the information environment is becoming increasingly digital and the IT has a wide ranging impact on library and information work. The drastic change in information technology has transformed the work culture in special libraries and brought new responsibilities to librarians. The phrase special libraries encompasses an enormous range of library types which do not fit comfortably into other categories of libraries such as public library or academic library. According to International Organization for Standardization (2000) special libraries are those libraries maintained by an association, government, parliament, research institutions, museums, business firms, industrial enterprise, chamber of commerce or organized groups with a greater part of their collection being in a specific subject or field. Also Cloonan, (2003) defined special library as a collection of information covering a specific field which may be administered by special staff and for service of a limited clientele.

The role of the special library is very closely related to its institutional activities, and is therefore mainly focused on making knowledge and expertise available to further the institution's goals. The service delivery of these libraries is based on the following ( Igwebuike \& Agbo, 2017)

A collection that is tailored to suit the needs of the clientele 
Collections and services that consider current needs more than possible future needs

The speed and accuracy of reference services

Proactive delivery of relevant information to users

Customized user services (personal profiles, alerting services, selective dissemination of information)

Efficient background services

Cost-efficiency of services

Collections within these institutions aim to serve the specific information needs of the organizations that they serve in order to increase the productivity and efficiency of the parent organization. This customization is achieved by reducing the time employees spend on data searching, and by providing information that can facilitate improved decision-making. The primary function of special libraries is to provide facilities and up-to-date information services for research and development of the parent organization.

Special libraries use different types of technology to enhance service delivery such as Computers with software, Online Public Access (OPAC), Marc, Laptops Photocopying and scanning machines, Internet, CDrom and DVDs, World cat. To be able to access and make use of information from information system available in a particular library, it usually to a large extent dependent on the method of information service delivery employed, therefore service delivery is the methods or channels through which the desired information/services are packaged, delivered or sent to the user who needs it.

\section{Statement of the Problem}

The primary function of special libraries is to provide facilities and up-to-date information services for research and development of the parent organization. But due to the failure of the existing traditional manual methods to cope efficiently with the increasing volume of work in the library, modern Technologies seems to have been found to be of tremendous importance in improving the services provided by special libraries as it ensures speed, efficiency, accurate record keeping and provision of up-to-date information, access and improved service. Hence the need for the study which is designed to examine the Utilization of Modern Technologies Use for Service Delivery in Special Libraries in South East Nigeria

\section{Aim of the Study}

The aim of this is to determine the utilization of modern technologies for 
effective service delivery in special libraries in South-East Nigeria. Specifically, the study seeks to:

1. Identify the available modern technologies used to provide services in the special libraries in south east Nigeria.

2. Ascertain the extent of utilization of the modern technologies in special libraries service delivery in the South East, Nigeria.

\section{Literature review}

\section{Uses of Modern Technology in Special}

\section{Libraries}

From the Global point of view, it appears that there is tacit consent that relationships exist between the use of information and communication technology and job enhancement of librarians. (Rezaei , Rezaei, Zare, \& Farid 2014) submits that the use of information Technology provides significant benefit in work measurement, cost reduction, productivity improvement service to customers and clients, actually it is availability which makes use possible and it is the use that makes performance attainable, that makes an excellent combination. According to Anyakoha (2005) technology has taken librarianship to a greater height, as tools that librarians used to serve their patrons have changed with the increasing application of modern technology. These tools and equipment can be utilized for the following library operation: resource sharing, digitized circulation services, current awareness services, information subscription and ordering, acquisition of information materials, creation and management of information analysis and design, information networking, selective dissemination of information, advisory services, bibliographic control services, lending and borrowing, website utility, research, online communication and information processing .

Chauhan (2004) also noted that the advent of computers with the ability to process large amount of information and output in a variety of formats has finally brought the library to the customer , wherever he or she may be located, in the form of Online public Access catalogue (OPAC). For improved capability computers and other modern technologies are essential tools now available to librarians for improving their services to their clientele. Application and utilization of information Technology to library operation 
allows easy integration of various activities. As special library are focused on provision of current awareness services, Modern technology helps in easy integrations of various activities such as Serials control, Circulation and Cataloguing with the use of appropriate telecommunication gadgets to computers it will facilitate local, regional and world wide Access to numerous textual database for scholars and professional librarians enhancing their job performance in information handling. The use of Modern Technology fosters easy and quick access to information. The delay that would have resulted due to manual operation is removed. Information can be gotten from a database at the press of a button compared to Days or weeks it will take if such information were to be obtained manually. Current information is also assured through the use of Modern Information Technologies (A law library with that is hooked internet access can easily get more information from the National Assembly library concerning a bill that was passed Introducing modern technologies will assist in solving a great deal of problems in addition to meeting the needs and requirement of the users. Furthermore, relying nowadays on conventional technical procedures in libraries in general and special libraries in particular has proved to be the wrong path to success, for that reason, a shift to information technology and its application would seem to be essential to give these institutions the capability of providing reliable services targeted at the end users. It is also important to point out in this context that information and communication technologies present new opportunities and chance for librarians in general and special librarians in particular. There seems to be a general agreement that special librarians are passing through a phase of dramatic changes due to the ongoing challenges being posed by information and communication technologies .so therefore they are challenged to explore new ways to imbibe and accept these change to be fit enough to serve the experts, scientist and research workers who always demand specialized services perfectly, faultlessly and accurately, in relation to these qualified well-trained staff and modern technological equipment should be available to boost technical procedure and services to an effective level and to enhance and foster productivity and expansion of research activity . 
Modern technologies are potentially made to compliment many of the services provided by special libraries and also extend them to other library users. They improve and promote information related activities (Ojedokun, 2000). From all the literature cited above, there is the resultant urge to investigate the utilization of modern technology in special libraries in the south East, Nigeria since most of the study under review focused basically on application of ICT which is a part of modern technologies, while the current study seeks to explore availability and use of modern technologies , not IT or ICT.

\section{Methodology}

The research design adopted for this study is descriptive survey. It is appropriate for this research because it will be used in accessing the attitude and opinion of staff in the utilization of modern technology for effective service delivery in special libraries in the south -East Nigeria. The population of the study is 30 special librarians. The population comprises of all the special librarians in the selected special libraries south East Nigeria. The libraries include; PRODA library Enugu (2 librarians), National Orthopedics Hospital library Enugu (3 librarians), CBN library Enugu (2 librarians), Energy Center, Nsukka (3
librarians).Ministry of Justice Owerri (1 librarian) and special library for the Blind, Owerri, Imo state (2 Librarians), National Root Crops Research Institute,[NRCRI], Umudike (10 Librarians) , College of Medicine Uturu (3 librarians), Abia State, Nnewi Teaching Hospital library,(1 librarian) Anambra state and Ebonyi State Teaching Hospital, Abakiliki (1 librarian) and Ebonyi state judiciary ( 2 librarians). Simple random sampling technique was Used to determine the sample size. The special librarians purposively selected were 30 from the selected libraries South East of Nigeria. This was used as the sample size for the study, because the sample size is managable. The instrument for data collection for this research is the questionnaire made up of four sections which help to obtain important data on the subject of the study. Data was collected by the researchers with the use of questionnaire The questionnaire was administered to the librarians personally by the researchers because of the small number of the population. The data was analyzed using mean score. Four responses options of questionnaires were assigned values, which were used to arrive at the criterion mean of 2.50. the result of the computation where it is either equal or greater than criterion 
mean was regarded a major factor -“ accepted ", conversely where it was less than criterion mean 2.50 was regarded not a major factor - “"'rejected ".

\section{Results}

A total of 30 copies of the questionnaire were distributed to the respondents in the selected special libraries in south east Nigeria, but out of 30 questionnaire 29 were returned completely filled. The response rate was $96.66 \%$.

\section{Research Question 1}

What are the available modern technologies that are used to provide services in special libraries?

Table 1: Frequency and Percentages of the Available Modern Technologies used to provide different services in special libraries.

\begin{tabular}{|c|c|c|c|c|c|c|}
\hline \multirow[t]{2}{*}{$\mathbf{S} / \mathbf{N}$} & \multirow{2}{*}{$\begin{array}{l}\text { Modern technologies in special } \\
\text { libraries }\end{array}$} & \multicolumn{2}{|c|}{ Available } & \multicolumn{2}{|c|}{ Not Available } & \multirow[t]{2}{*}{ Remark } \\
\hline & & Freq & $\%$ & Freq. & $\%$ & \\
\hline 1 & Online database & 4 & 36.4 & 7 & 63.6 & Not Available \\
\hline 2 & Internet facilities & 10 & 90.6 & 1 & 9.1 & Available \\
\hline 3 & CD-Rom & 8 & 72.7 & 3 & 27.3 & Available \\
\hline 4 & Online Public Access Catalogue & 1 & 9.1 & 10 & 90.9 & Not Available \\
\hline 5 & Scanners & 9 & 81.8 & 2 & 18.2 & Available \\
\hline 6 & Printers & 10 & 100.0 & 0 & 0.0 & Available \\
\hline 7 & Library based software & 5 & 45.5 & 6 & 54.5 & Not Available \\
\hline 8 & Telefascimile Equipment & 2 & 18.5 & 9 & 81.8 & Not Available \\
\hline 9 & Local Area Network (LAN) & 8 & 72.7 & 3 & 27.3 & Available \\
\hline 10 & Wide Area Network (WAN) & 8 & 72.7 & 3 & 27.3 & Available \\
\hline 11 & $\begin{array}{l}\text { Machine Readable Catalogue } \\
\text { (MARC) }\end{array}$ & 2 & 18.5 & 9 & 81.8 & Not Available \\
\hline 12 & Radio/recordings & 1 & 9.1 & 10 & 90.9 & Not Available \\
\hline 13 & Connected Computers & 8 & 72.7 & 3 & 27.3 & Available \\
\hline 14 & DVD -Rom & 10 & 90.6 & 1 & 9.1 & Available \\
\hline
\end{tabular}




\begin{tabular}{|c|c|c|c|c|c|c|}
\hline 15 & Projectors & 7 & 63.6 & 4 & 36.4 & Available \\
\hline 16 & E-Book & 5 & 45.5 & 6 & 54.5 & Not Available \\
\hline 17 & E-Journal & 1 & 9.1 & 10 & 90.9 & Not Available \\
\hline 18 & Security cameras & 3 & 27.3 & 8 & 72.7 & Not Available \\
\hline 19 & Electronic Bulletin Boards & 1 & 9.1 & 10 & 90.9 & Not Available \\
\hline 20 & 3-D printers & 2 & 18.5 & 9 & 81.8 & Not Available \\
\hline 21 & Brailles & 2 & 18.5 & 9 & 81.8 & Not Available \\
\hline 22 & Digital imaging \& media technology & 1 & 9.1 & 10 & 90.9 & Not Available \\
\hline 23 & Book Delivery Robot & 0 & 0.0 & 10 & 100.0 & Not Available \\
\hline $\begin{array}{l}\text { The } \\
\text { tech } \\
\text { libr } \\
\text { cam } \\
\text { Bra } \\
\text { con } \\
\text { the } \\
\text { reve } \\
\text { libr } \\
\text { DV } \\
\text { spe } \\
\text { whi }\end{array}$ & $\begin{array}{l}\text { table showed list of modern } \\
\text { ologies that available in special } \\
\text { ies such as printers, scanners, security } \\
\text { ras, bulletin board, internet facilities, } \\
\text { le, library based software, connected } \\
\text { uters etc. However, ranking highest in } \\
\text { requency is the printers with } 100.0 \\
\text { ling that most of all the special } \\
\text { ies have them. Internet facilities and } \\
\text {-ROM ranked } 90.6 \text { Some of the } \\
\text { al libraries have connected computers } \\
h \text { they use to connect to the internet for }\end{array}$ & & \multicolumn{4}{|c|}{$\begin{array}{l}\text { service delivery. DVD-ROM is use to store } \\
\text { data. Other technologies such as book } \\
\text { elivery robot, digital imaging \& media } \\
\text { wehnology, electronic bulletin board and 3D } \\
\text { printers are not available. Infact some of the } \\
\text { librarians confessed that they have not seen } \\
\text { any of such technologies, this reflected in } \\
\text { the frequency been 00.0. } \\
\text { Research Question 2: What is the extent of } \\
\text { utilization of modern technologies in special } \\
\text { libraries south east? }\end{array}$} \\
\hline
\end{tabular}

Table 2: The mean and standard deviation on the extent of utilization of modern technology in the special libraries

\begin{tabular}{llcccccccc}
\hline No & Items & VH & HE & LE & VLE Mean SD & Rank Decision \\
& & E & & & & & & \\
\hline 1 & Internet facilities & 10 & 18 & 6 & 1 & 3.06 & 0.77 & $1^{\text {st }}$ & High Extent \\
2 & Use of search engines & 15 & 10 & 7 & 3 & 3.06 & 1.00 & $1^{\text {st }}$ & High Extent \\
& e.g Google & & & & & & & & \\
3 & CD-Rom & 9 & 13 & 10 & 3 & 2.80 & 0.93 & $2^{\text {nd }}$ & High Extent \\
\hline
\end{tabular}




\begin{tabular}{llllllllll}
\hline 4 & Connected computers & 9 & 14 & 6 & 6 & 2.74 & 1.04 & $3^{\text {rd }}$ & High Extent \\
5 & Library software & 9 & 8 & 15 & 3 & 2.66 & 0.97 & $4^{\text {th }}$ & High Extent \\
6 & DVD-Rom & 11 & 9 & 7 & 8 & 2.66 & 1.16 & $4^{\text {th }}$ & High Extent \\
7 & Online database & 14 & 2 & 11 & 8 & 2.63 & 1.24 & $5^{\text {th }}$ & High Extent \\
8 & Projectors & 6 & 12 & 4 & 13 & 2.31 & 1.16 & $6^{\text {th }}$ & Low Extent \\
9 & E-books & 6 & 9 & 8 & 12 & 2.26 & 1.12 & $7^{\text {th }}$ & Low Extent \\
10 & Online catalogue & 5 & 3 & 13 & 14 & 1.97 & 1.04 & $8^{\text {th }}$ & Low Extent \\
11 & 3-D printers & 4 & 10 & 2 & 19 & 1.97 & 1.15 & $8^{\text {th }}$ & Low Extent \\
12 & E-journals & 4 & 8 & 1 & 22 & 1.83 & 1.15 & $9^{\text {th }}$ & Low Extent \\
13 & Electronic bulletin & 4 & 3 & 3 & 25 & 1.60 & 1.06 & $10^{\text {th }}$ & Low Extent \\
& boards & & & & & & & &
\end{tabular}

$\begin{array}{llllllllll}14 & \text { Security cameras } & 4 & 2 & 5 & 24 & 1.60 & 1.04 & 11^{\text {th }} & \text { Low Extent }\end{array}$

15 GPs Apps that help $\quad \begin{array}{lllllllll}2 & 6 & 2 & 25 & 1.57 & 0.98 & 12^{\text {th }} & \text { Low } & \text { Extent }\end{array}$ locate materials

$\begin{array}{llllllllll}16 & \text { Telefascimile Equipment } & 4 & 2 & 4 & 25 & 1.57 & 1.04 & 12^{\text {th }} & \text { Low Extent }\end{array}$

$\begin{array}{llllllllll}17 & \text { Online public access } & 0 & 7 & 5 & 23 & 1.54 & 0.82 & 13^{\text {th }} & \text { Low Extent }\end{array}$ catalogue (OPAC)

18 Machine readable $\quad \begin{array}{lllllllll} & 1 & 4 & 7 & 23 & 1.51 & 0.82 & 14^{\text {th }} & \text { Low Extent }\end{array}$ catalogue (MARC)

19 Book delivery Robot $\quad \begin{array}{lllllllll}2 & 4 & 1 & 28 & 1.43 & 0.92 & 15^{\text {th }} & \text { Low Extent }\end{array}$

20 Direct image $\quad \begin{array}{llllllll}0 & 2 & 7 & 26 & 1.31 & 0.58 & 16^{\text {th }} & \text { Low Extent }\end{array}$
reprography machine

21 Radio/recordings $\quad \begin{array}{lllllllll}10 & 9 & 7 & 8 & 2.66 & 1.16 & 4^{\text {th }} & \text { High Extent }\end{array}$

Key: VHE-very great extent. HE- great extent $\quad$ LE-low extent VLE- very low extent

Table 2 reveals that out of the 20 listed items special librarians' use of internet facilities and search engines such as Google and Mozilla Firefox to serve their users have the highest mean score as both are ranked $1^{\text {st }}$ with 3.06 . The use of storage 
device CD-Rom ranked second with 2.80, followed by library software 2.66 . Only 8 items were recorded high extent

\section{Discussion}

The findings of this study are discussed under the following subheadings:

\section{Available modern technologies used for different library services for effective delivery in special libraries.}

The study reveals that modern technologies used in service delivery are connected computers ,laptops, electronic bulletin boards, security cameras, Opac, Marc, Braille, projectors, internet facilities, library software, DVD sets, utilized in carrying virtually all the library services, such as referral services, information sourcing, information retrieval, storage, online referencing resource sharing, classification and cataloguing ,training programe, user education, selective information dissemination, inter-library loans, reference services and database loans which makes the library services more efficient and effective. Apparently, it disclosed that connected computers, CDRom, internet facilities were mostly available in the selected special librarie understudy. This agrees with the statement made by Walsh (2016) who stated that modern technologies are essential for survival of information service, he also reaffirmed that it also creates good opportunity for librarian to grow and strengthen relationship with the library users, same with Gary(2010) who supported by saying that technology plays a significant role in the delivery of modern library management system and catalogues. That is to say, libraries especially special librarians who have a delicate task to serve people with special and peculiar needs, must as a matter of fact use modern technologies in carrying out their services in this present age and time.

\section{The extent of utilization of the available} modern technologies in the selected special libraries

The extent of modern technology use is extensively dependant on its availability, workability and maintenance culture of the technology and skills of the technicians or librarians as the case maybe. The checklist revealed that most technologies that are needed in the special libraries are not available while the available ones are either obsolete or faulty; some are equally dormant because of the erratic power supply. It was discovered that most desktop computers that are not even connected to the internet, some storage instruments like CD-ROMs have been 
overused, some printers and scanners are packed up , telefascimile equipment have been replaced by individual cell phones, these were the few technology available..

Technologies such as projectors which can be readily use to project seminar talks for staff of the company for instance, are in less extent so also E-books, which staff can download, open and read at the comfort of his/her office are in less extent 3D printer (fast and efficient) e-journals, electronic bulletin display, and most especially and importantly security cameras which can be used to checkmate loss of library materials were not in existence. In essence the extent of modern technology usage is low compared to what is expected. Oni (2004) posited by saying that it is beneficial to invest in modern technology but effective implementation is the key especially when it involves knowledge of recent technology trends.

\section{Recommendations}

- Adequate fund should be provided for the procurement of modern technologies facilities in these special libraries to ensure better performance.

- There is need for the training of librarians/library staff on to enable them cope with the challenges of modern technologies application.

- Management of special libraries should encourage the application of these technologies in those areas in which they are not applied to meet up with the ever increasing demands of the clients

- Maintenance of the available modern facilities is necessary to ensure constant functionality.

\section{Conclusion}

Modern technologies in libraries are changing the work of librarians more than before and so they need adequate and relevant modern technologies to attend to the needs of their users. They should also be aware of the latest technologies to continue and maintain the importance of the service offering. Utilization of modern technologies in special libraries is optimistic to gain right information at the right time in the right place and at the right cost.. In the light of the above, special libraries budget in Nigeria should be increased to accommodate and initiate the implementation of modern technologies for effective service delivery. 


\section{References}

Anyakoha, M.W. (2005) Information and communication technology (ICT) in library and information service. Coal City libraries. 2 (1\&2) 1-2.

Chauhan, B.P. (2004) ICT enabled library and information services. Winter school on ICT enabled library and information service. Trent Patiala.

Cloonan, M.V. (2003). The continuing development of special collection librarianship. Library Trends. 52 (1), 9.

Cissse, C. (2004). Access to electronic information and information research. Scaulwa Newsletter 5 (1) $14-17$.

.Gary, B.S. (2010) Discovering computers 2010-John Bowne high school. Johnbowne.enschool.org...discover $\% 20$ computers.Retrieved from books.google.com-computers .general. July 17, 2016.

Igwebuike, E.U \& Agbo, A.D(2017). Improving ICT Application to library and Information services in Special Libraries in Nigeria. Journal of Applied Information Science \& Technology10(2), 102-110

Issa, W.O.A. (2010). Imperative and challenges of computer applications in Libraries. Modern library and information science for information professional in Africa: Ibadan. Text links publishers. 1-7

Ojedokun, A.A. (2000). Prospects of digital libraries in African. African Journal of library, Archives and information science.10 (1). April 2000.

Rendon, F. (2014) How Innovation and Technology are shaping libraries of today.Huffpost Books. Blog.

Rezaei,M, Rezaei,Maryam, Zare,Majid,A \& Zare,Farid(2014). The Effect of ICT on Employee Productivity in Shahr Bank( case study of Shiraz,Iran). Special Issue in Management \& Technology ,p1208-1214

Rouse, M. (2005) ICT (Information Communication Technology). Searchcio.Techtarget.com

SENEC (2011) South East Nigeria Economic Communitywww.SENEC.org.ng

Shayo, C. and Magid, I. (2003). Information Technology Adoption. Encyclopedia of Library and Information Science. 2 (1358-1368).

Udin, M.J \& Hasan,M.N (2012). Use of Information Technology in Library Service; A study on some Selected libraries in Northern Part of Bangladesh. International Journal of Library and Information Science,4(3),34-44. Available on http;//www.academicjournals.org/IJ LIS

Walsh, A. (2016). Using Mobile Technology to deliver library services; a handbook. Facet; London. http//www.facetpublishing.co.uk/titl e.com 